\title{
LEADERSHIP, CHARACTER AND ITS DEVELOPMENT: A QUALITATIVE EXPLORATION
}

\author{
ROSLYN DE BRAINE \\ roslynd@uj.ac.za \\ Department of Human Resource Management \\ University of Johannesburg \\ DEREK VERRIER \\ Derek@nurcha.org.za \\ NURCHA
}

\begin{abstract}
The purpose of this study was to explore (1) what organisational leaders consider to be character elements of leaders within the workplace, (2) what influences leaders' character development, and (3) how an organisation can continue the process of character development. The literature review and findings revealed that leadership, integrity, industriousness, empathy, loyalty, optimism, fairness and compassion are the most sought after character elements within leaders in the workplace. Leadership and integrity were found to be the most supported character elements. The findings also indicate that work environmental factors, a person's own efforts, and the daily experiences of work life contribute towards character development.
\end{abstract}

Key words

Character, leadership, development, integrity, virtues, strengths

Great leaders throughout the history of man have won battles, called the command of nations and won the respect and admiration of their followers based on their character. People today are seeking to follow leaders that not only demonstrate the necessary leadership competencies, but also leaders that exhibit character, integrity, courage and consideration (Covey, 1997). Character communicates consistency, potential and respect to followers (Maxwell, 1998). Followers then emulate their leaders, which inevitably contributes to the building of character at all organisational levels, and ultimately strengthens the organisation and its bottom-line (Turknett, Turknett \& McCusker, 2006). This provides the impetus for this study's exploration of what influences the development of character in leaders.

The researchers' interest in studying the development of character in leaders was also roused by a statement made by Joseph Badarocco (1997, p. 2), a leading authority on business ethics. He stated that leaders are suffering from a "dirty hands problem". Badarocco derived this from Jean Paul Sartre, a French philosopher, who made use of this metaphor in his play of the same name, in which he demonstrated how leaders involve themselves in activities that are morally destructive. Major corporations such as Enron, WorldCom, Global Crossing, Anderson Consulting and Tyco (Klann, 2003; Miller, 2004; Storey, 2003) have seen their leaders suffer from this "dirty hands problem." These organisations, along with others, fell prey to the greed of their leaders in various forms, ranging from "massaging" numbers ("managed earnings") to outright fraud (Beatty, Ewing \& Tharp, 2003). These examples of leadership crisis partially stems from the crisis of character in individual leaders (Sankar, 2003). This has resulted in employees losing their jobs, companies filing for bankruptcy (Storey, 2003), the loss of employee life savings plans (Gray \& Clark, 2002), increased levels of cynicism and suspicion (Farmer, 2005), and public disenchantment (Storr, 2004).

This leadership crisis could be attributed to leaders choosing to operate out of what Cashman (1998) calls persona (leading on the outside), which limits possibilities and potentialities and which is guided by control, fear, self-interest and winning at all costs. Instead, Cashman states that people should be leading out of character (leading from the inside-out), which opens up possibilities and potentialities and allows a leader to be guided by authenticity, purpose, openness, trust and compassion. This problem is further exacerbated by the spirit of this age which revolves around material gain and a consumer mentality (Maxwell, 2002). This consumer drive has caused leaders to pursue performance goals, whereby they forget that enduring positive influence depends on the "type of people they are and not merely on power, titles and positions" (Klann, 2003, p. 4).

Of the many leadership theories that exist today, there are a few that place significant emphasis on the type of people that leaders are and the importance of character or elements thereof. One such theory is the Personal and Professional Leadership Perspective (PiPL). Smith (2004), the founder of PiPL, states that personal leadership begins with knowing where one stands now as a leader. To become a personal leader, requires a person to become principle-centered, character-based and to lead from the inside-out (Covey, 1994). According to Verrier (2004) personal leadership in the PiPL context forms the foundation for interaction with people (interpersonal leadership) and also for professional leadership that is based on teamwork, relationship building and empathic listening. Authentic leadership is also an important perspective taken into consideration in this study. According to Luthans and Avolio (2003), cited in Ilies, Morgeson and Nahrgang (2005, p. 376), authentic leadership is defined as a process that combines positive leader capacities and a highly developed organisational context. Luthans and Avolio (2003) further hold that the authentic leader displays confidence, hopefulness, optimism, morality, and future-orientedness and gives priority to developing associates to be leaders. Servant leadership is another form of leadership that considers character to be important. To be a servant leader requires "serving with compassion and heart" and enriching and empowering participants (Jaworski \& Senge, 1996, p. 60). Servant leaders also demonstrate empathy, self-awareness and commitment to the growth of people, according to Larry Spears (2006), the chief executive officer of the Greenleaf Center for Servant Leadership. The abovementioned attributes associated with the description of personal leaders, authentic leaders and servant leaders are all considered important elements of character.

Integrity, a character element, is also regarded as an important attribute for leadership (Maxwell, 2002). According to Covey (2004), integrity is one of the three facets of personal character, together with maturity and an abundance mentality. He states that these provide the foundation for great achievement and 
trust. Integrity is also considered a challenge that organisations face in managing ethical behaviour (Rossouw \& van Vuuren, 2003). Ethically led organisations display stronger organisational culture, lower levels of staff turnover and increased employee effort (Storr, 2004). This in turn supports the organisation to fulfill what Bellingham (2003) calls an external moral responsibility towards customers and the greater community in which trading occurs.

Certain character elements, such as perseverance, for instance, is known to increase one's chances of attaining difficult goals, improving skills and resourcefulness, enhancing self-efficacy and is considered to be a key personal characteristic required for successful entrepreneurship (Peterson \& Seligman, 2004). Other examples include curiosity and the love of learning; both having a positive relationship with leadership development (Peterson \& Seligman, 2004). Self-knowledge and a strong belief in oneself, for example, are known to enable one to achieve career maturity (Coetzee, 2006).

The above discussion suggests that greed, the spirit of this age, and leaders leading out of persona, not character, has caused the downfall of many organisations. One of the remedies to this problem is to create work environments that optimize the development of character in people. Although character forms from experiences and influences in childhood and adolescence, character development is a continuous life-long process, some of it occurring within the workplace (Klann, 2003).

The threefold aim of this article is to explore what organisational leaders consider to be the key character elements of leaders, what influences leaders' character development, and how organisations can continue the process of character development in their leaders. In order to address the above questions, a literature review was conducted, in which character was defined and its constituent elements explored. Thereafter empirical interviews with leaders were carried out to further address the above research aims.

\section{What is character?}

In the early 5 th century $\mathrm{BC}$ the Greeks held that character was a distinguishing mark of an individual's ideals and conduct as judged in terms of values and strength of will (Halsey \& Friedman, 1981, p. 700). The great Greek philosopher Aristotle held that there are two kinds of human excellences: excellences of thought, and excellences of character. Excellences of character - ethikai aretai - is usually translated as "moral virtue(s)" or "moral excellences." The Greek word ethikos (ethical) is the adjective cognate with ethos, which is character (Stanford Encyclopedia of Philosophy, 2003). Aristotle also viewed good character as the life of right conduct - right conduct in relation to other persons and in relation to oneself (Lickona, 1994). This view is supported by Nucci (1997) and Wynne and Walberg (cited in Huitt, 2004). Aristotle held that character consists of moral virtues, these being self-oriented virtues (such as self-control and moderation) as well as other-oriented virtues (such as generosity and compassion) (Lickona, 1994).

Thomas Lickona (1994), a moral educationist, also supports the Aristotelian notion of character. He argues that character consists of operative values, being values in action and that people progress in their character as a value becomes a virtue (a reliable inner disposition to respond to situations in a morally good way). This notion of operative values is supported by leadership writers Manning and Curtis (2003, p. 93); they state that "character is based on a value system that is known, cherished, stated and lived habitually."

Some theorists, specifically in the field of psychology, view character as the accumulation of traits or habits required to live a successful life. Corsini's definition (1999, p. 155) considers character to be the total qualities or traits, particularly characteristic of the moral, social and religious attitudes of a person. Positive psychologists define character in terms of positive traits that have emerged across cultures and throughout history as important for a good life (Park, 2004, p. 46). Character is also perceived as consisting of habits (Baumrind, 1998, p. 4, cited in Park, 2004). Baumrind holds that "character refers to such positive and cultivated habits such as social responsibility, moral commitment, self-discipline and resoluteness by which constellation the whole person is judged to be deficient, adequate, or exemplary." Smith $(2005$, p. 4) considers character to be an expression of one's moral orientation, willpower, conscience and principles.

Crystallizing the above definitions of character, into a single, composite definition, the researchers define character as follows:

Character refers to positive and cultivated traits that become habits by which the whole person is judged to be exemplary.

So far in the discussion of the various definitions or views of character from various scientific disciplines, character is seen in various ways as the accumulation of "moral virtues" or "operative values" or "positive traits" or "cultivated habits." For the purposes of this article these various ways of viewing character will be termed "elements of character." What follows then, is a brief explanation and listing of what a few theorists, particularly in the field of psychology, education and leadership believe to be the constituent elements of character. These theorists have done extensive research on character and its development and are therefore regarded to be authoritative on the topic.

\section{The constituent elements of character}

Positive Psychology's hierarchical classification scheme of character, as expounded by Peterson and Seligman (2004), as based on the literature review, is one of the most comprehensive and easy to understand categorizations of character traits. Their classification scheme of character is modelled on the Linnaean classification of species and distinguishes three conceptual levels of character as follows:

- Conceptual level 1: Virtues.

These are the core characteristics valued by moral philosophers and religious thinkers:

- Wisdom and knowledge: cognitive strengths that entail the acquisition and use of knowledge.

- Courage: emotional strengths that involve the exercise of will to accomplish goals in the face of opposition, external or internal

- Humanity: interpersonal strengths that involve tending and befriending others

- Justice: civic strengths that underlie healthy community life

- Temperance: strengths that protect against excess

- Transcendence: strengths that forge connections to the larger universe and provide meaning.

(Table 1 overleaf provides a brief description of the associated character strengths of each of the above virtues.)

- Conceptual level 2: Character Strengths.

These are the psychological ingredients - processes or mechanisms that define the virtues. They are distinguishable routes to displaying one or another of the virtues. (listed in Table 1)

- Conceptual level 3: Situational Themes.

These are the specific habits that lead people to manifest given character strengths in given situations. 
TABLE 1

\section{Classification OF VIRTUES AND CHARACTER STRENGTHS}

\begin{tabular}{|c|c|}
\hline VIRTUE & ASSOCIATED CHARACTER STRENGTHS \\
\hline $\begin{array}{l}\text { Wisdom \& } \\
\text { knowledge }\end{array}$ & $\begin{array}{l}\text { Creativity (originality, ingenuity): Thinking of novel and } \\
\text { productive ways to conceptualize and do things; includes } \\
\text { artistic achievement but is not limited to it. } \\
\text { Curiosity (interest, novelty-seeking, and openness to } \\
\text { experience): Taking an interest in ongoing experience for its } \\
\text { own sake; finding subjects and topics fascinating; exploring and } \\
\text { discovering. } \\
\text { Open-mindedness (judgement, critical thinking): Thinking } \\
\text { things through and examining them from all sides; not } \\
\text { jumping to conclusions; being able to change one's mind in } \\
\text { light of evidence; weighing all evidence fairly. } \\
\text { Love of learning: Mastering new skills, topics, and bodies of } \\
\text { knowledge, whether on one's own or formally; obviously } \\
\text { related to the strength of curiosity but goes beyond it to de- } \\
\text { scribe the tendency to add systematically to what one knows. } \\
\text { Perspective (wisdom): Being able to provide wise counsel to } \\
\text { others; having ways of looking at the world that make sense to } \\
\text { oneself and to other people. }\end{array}$ \\
\hline
\end{tabular}

Courage Bravery (valour): Not shrinking from threat, challenge, difficulty, or pain; speaking up for what is right even if there is opposition; acting on convictions even if unpopular; includes physical bravery but is not limited to it.

Persistence (perseverance, industriousness): Finishing what one starts; persisting in a course of action in spite of obstacles; "getting it out the door"; taking pleasure in completing tasks. Integrity (authenticity, honesty): Speaking the truth but more broadly presenting oneself in a genuine way and acting in a sincere way; being without pretense; taking responsibility for one's feelings and actions.

Vitality (zest, enthusiasm, vigour, energy): Approaching life with excitement and energy; not doing things halfway or halfheartedly; living life as an adventure; feeling alive and activated.

Humanity Love: Valuing close relations with others, in particular those in which sharing and caring are reciprocated; being close to people. Kindness (generosity, nurturance, care, compassion, altruistic love, "niceness"): Doing favours and good deeds for others; helping them; taking care of them.

Social intelligence (emotional intelligence, personal intelligence): Being aware of the motives and feelings of other people and oneself; knowing what to do to fit into different social situations; knowing what makes other people tick.

Justice Citizenship (social responsibility, loyalty, teamwork): Working well as a member of a group or team; being loyal to the group; doing one's share.

Fairness: Treating people the same according to notions of fairness and justice; not letting personal feelings bias decisions about others; giving everyone a fair chance.

Leadership: Encouraging a group of which one is a member to get things done and at the same time maintain good relations within the group; organising group activities and seeing that they happen.

Temperance Forgiveness and mercy: Forgiving those who have done wrong; accepting the shortcomings of others; giving people a second chance; not being vengeful.

Humility/modesty: Letting one's accomplishments speak for themselves; not seeking the spotlight; not regarding oneself as more special than one is.

Prudence: Being careful about one's choices; not taking undue risks; not saying or doing things that might later be regretted. Self-regulation (self-control): Regulating what one feels and does; being disciplined; controlling one's appetites and emotions.

Transcen- Appreciation of beauty and excellence (awe, wonder,

dence elevation): Noticing and appreciating beauty, excellence, and/or skilled performance in various domains of life, from nature to art to mathematics to science to everyday experience. Gratitude: Being aware of and thankful for the good things that happen; taking time to express thanks.

Hope (optimism, future-mindedness, and futureorientation): Expecting the best in the future and working to achieve it; believing that a good future is something that can be brought about.

Humour (playfulness): Liking to laugh and tease; bringing smiles to other people; seeing the light side; making (not necessarily telling) jokes.

Spirituality (religiousness, faith, purpose): Having coherent beliefs about the higher purpose and meaning of the universe; knowing where one fits within the larger scheme; having beliefs about the meaning of life that shape conduct and provide comfort.

Source: Peterson and Seligman (2004, pp. 29-30)
According to Barnard (2003, p. 22) humans have the potential for morality, the ability to choose between "good" or "bad". Lickona (1994) characterised the components of good character in three interrelated parts: moral knowing (knowing the good), moral feeling (desiring the good) and moral behaviour (doing the good), as shown in Table 2.

TABLE 2

COMPONENTS OF GOOD CHARACTER

\begin{tabular}{ll}
\hline & MORAL KNOWING \\
\hline Moral Component & Description \\
\hline 1. Moral awareness & People often don't see a situation that involves a
\end{tabular}
moral issue and that requires moral judgement. People use their intelligence to see when a situation requires moral judgement.

2. Knowing moral values Gets passed from one generation to another; ethical literacy and its application requires knowing these values.

3. Perspective taking This is the ability to take the viewpoint of other people, see a situation as they see it, and imagine how they might think, react and feel. It is a prerequisite for moral judgement.

4. Moral reasoning Involves understanding what it means to be moral and why we should be moral. Growth is gradual and children learn what counts as good moral reason and what does not count. Respect the intrinsic worth of every individual.

5. Decision-making Thinking one's way through a moral problem. Asking the questions: What are my choices and what are the consequences?

\section{MORAL FEELING}

1. Conscience A mature conscience includes : a sense of moral

2. Self-esteem A healthy measure of self-esteem helps us to obligation and the capacity for constructive guilt value ourselves and be less dependent on the approval of others. Self positive regard has a positive correlation with treating others positively.

3. Empathy This is identification with, or vicarious experience of, the state of another person/ emotional side of perspective taking.

4. Loving the good The highest form of character includes being genuinely attracted to the good. When people love the good, they take pleasure in doing good. They have a morality of desire, not just a morality of duty. Part of the moral potential of ordinary people, even children.

5. Self-control Emotion can overwhelm reason, that's one reason why self-control is a necessary moral virtue. Selfcontrol helps us to be ethical even when we don't want to. It is also necessary to curb selfindulgence.

\begin{tabular}{|c|c|}
\hline & MORAL ACTION \\
\hline 1. Competence & $\begin{array}{l}\text { Moral competence is having the ability to turn } \\
\text { moral judgement and feeling into effective } \\
\text { moral action. }\end{array}$ \\
\hline 2. Will & $\begin{array}{l}\text { The right choice in a moral situation is usually } \\
\text { the hard one. Will is the mobilizing of moral } \\
\text { energy to do what we think we should. It takes } \\
\text { will to keep emotion under the control of reason. } \\
\text { It takes will to see and think through all the } \\
\text { moral dimensions of a situation. It takes will to } \\
\text { put duty before pleasure. Will is the core of } \\
\text { moral courage. }\end{array}$ \\
\hline 3. Habit & Moral conduct benefits from habit. \\
\hline
\end{tabular}

Source: Lickona (1991, pp. 53-62)

McElmeel (2002), a moral educationist, lists the following character traits: caring, confidence, courage, curiosity, flexibility, friendship, goal setting, humility, humour, initiative, integrity, patience, perseverance, positive attitude, problem-solving, selfdiscipline and teamwork. 
Another prominent writer on character is Covey (1994). According to Covey exhibiting the character ethic truly allows one to experience true success and enduring happiness. The principles of the character ethic include integrity, humility, fidelity, temperance, courage, justice, patience and industry.

Certain character traits have been identified as important for the workplace and specifically for leaders. Sankar (2003), for instance, maintains that a leader's character should be grounded on core values such as integrity, trust, truth and human dignity which influence the leader's vision, ethics and behaviour. This stance is supported by the Josephson Institute (2006). They hold that there are six core ethical values associated with character, namely: trustworthiness, respect, responsibility, fairness, caring and citizenship. John Adair (2003) mentions that there are certain qualities that are the hallmarks of good leaders: integrity, enthusiasm, warmth, calmness, being tough but fair and courage.

From the above exposition of the constituent elements of character, as proposed by various expert authors, the researchers propose that character be classified, using the following dimensions:

- Cognitive dimensions (evident in the virtues wisdom and knowledge and their associated character strengths and also encompassing moral knowing)

- Emotional dimension (evident in the virtues courage and humanity and their associated character strengths)

- Spiritual dimension (evident in the virtue transcendence and its associated character strengths)

- Social dimension (evident in the virtues courage, humanity, justice and temperance and their associated character strengths)

The researchers further suggest that the above dimensions are interdependent. This assertion is based on Smith's (2004) life dimension's model.

As the various character elements become cultivated habits in the life of person, a person's behaviour becomes exemplary. The question then arises, what influences the cultivation or development of character in individuals? Empirical studies are available that have looked at the development of certain character strengths. However, there are no investigations of the development of character as a family of positive traits - a multidimensional construct (Park, 2004). What follows then is a brief explanation of the different perspectives on character development. It is by no means exhaustive but for the purposes of this article, a brief description of each approach to character development is given.

\section{Character development}

Character development is a process in which the character of an individual develops from the possibilities which nature supplies and within the framework of environmental or cultural factors. Character, however, is also a unique achievement contributed to by an individual's creativeness, effort and striving (Halsey \& Friedman, 1981, p. 700). Psychological approaches to character development take into consideration environmental and cultural factors.

\section{Psychological approaches:}

According to Park (2004), there are a variety of influences that contribute to the development of good character. One such influence is parenting styles, particularly the authoritative parenting style, which has been consistently associated with childrens' prosocial behaviours like sharing with peers, selfcontrol and self-confidence. Secondly, positive role modelling, coupled with appropriate reinforcement, is known to facilitate prosocial behaviours such as sharing, helping and being a good team-mate. Social observational learning occurs due to the operant and cognitive principles at work indicated by the observation of others, reinforcement, and the use of rewards
(Jordaan \& Jordaan, 1998). Close relationships with family members and friends also perform a role in the development of good character (Park, 2004). Sibling relationships, for example, provide opportunities for children to develop character strengths like social intelligence and social problem-solving skills. Park also holds that moral education in schools enhances moral thinking, specifically among high school students.

A cultural-social approach or framework to moral development can also be taken (Haste, Markoulis \& Helkamal, 1999). According to Anderson (1997), nearly all societies have instruction and "rites of passage" which are intended to mould the character of a child into a loyal and productive citizen. Park (2004) maintains that moral culture and values of societies and communities influence character development. The character of humans then becomes "social in its institution" (Hunter, 2000, p. 15). Moral development occurs as the individual's skill in managing the moral expectations of his or her culture grows which is finally expressed through linguistic and symbolic practices (Haste et al., 1999).

Kohlberg's theory on moral development is also of relevance here (Barger, 2000). Kohlberg held that most moral development occurs through social interaction and that the progression of moral reasoning occurs through six identifiable stages. His theory focused on the development of cognitive processes, especially reasoning about obligation, rights and justice (Haste et al., 1999). Kohlberg also stated that the majority of adults never reach stage six in moral development (Barger, 2000). This stage is characterised by respect for universal principles and the demands of social conscience. Moral development can be advanced educationally, using social interaction, cognitive conflict, a positive moral atmosphere and democratic participation (Kohlberg, 1969, cited in McDaniel, 1998). Lifespan developmental psychology's stance on development supports Kohlberg's idea that development occurs through continual change and transformation through successively complex systems or stages (Haste et al., 1999). Adults are expected to show more integrated and elaborate morality, but not all adults show equal levels of 'moral maturity' (Haste et al., 1999, p. 318). Philosophical approaches to character development also consider the influence that social interaction and political institutions has on moral development.

Philosophical approaches:

Aristotle and Plato held that education of our emotional responses is crucial for the development of virtuous character (Stanford Encyclopaedia of Philosophy, 2003). Aristotle states that virtue is the state that makes a human being good and makes him perform his function well. He believes that the virtuous person is characterised by a nonstereotypical self-love. Self-love is developed and preserved through friendships in which individuals come to desire the good of others' own sakes and political institutions that promote the conditions under which self-love and friendship flourish (Stanford Encyclopaedia of Philosophy, 2003).

Philosophy also views character development as being the responsibility of the individual. This is stipulated in the definition of character development according to Halsey and Friedman (1981, p. 700). Virtues are seen as "an activity of the soul" (Lickona, 1991, p. 51) and are acquired through trial and error (Peterson \& Seligman, 2004, p. 46). Immanuel Kant's Doctrine of Virtue, also provides some light into the development of character through a person's own efforts. Kant states that we are always fighting against the impulses and dispositions that oppose the moral law, therefore we need strength of will and selfmastery to fulfill our imperfect duties (Stanford Encyclopedia of Philosophy, 2003). Many people follow the moral law that is taught to them from their religious beliefs. Consequently, character is also understood as being related to the religious attitudes of a person (Corsini, 1999). A brief description of the major religions' stances on moral virtues follows: 


\section{Religious approaches:}

\section{Judeo-Christian}

Judeo-Christian virtues are promulgated and taught within the Old and New Testament of the Bible, the religious text of followers of both Judaism and Christianity. The Old Testament has two sections that are particularly illustrative of virtues esteemed by Jewish culture and Christians: the Ten Commandments and the two books of Proverbs that specifically instruct on the consequences of virtues and vices (Peterson \& Seligman, 2004). Virtues such as integrity, righteousness, humility and trustworthiness are advocated in Proverbs. In the Christian faith character development is believed to be brought about through trials and perseverance (Romans 5:3-4 in NIV).

\section{Islam}

Muslims obtain their moral teachings from the $\mathrm{Qu}^{\prime}$ ran, the Muslim bible. Some of the values espoused by the $\mathrm{Qu}$ 'ran include humility, modesty, control of passions and integrity (www.iad.org/Islam)

\section{Confucianism:}

There are four or five central virtues espoused in the tenets of Confucianism: jen (translated as humanity or humanheartedness or benevolence), yi (duty or justice or equity), li (etiquette or observance of the rites of ceremonious behaviour), zhi (wisdom or perspicacity), and possibly, xin (truthfulness or sincerity or good faith) (Peterson \& Seligman, 2004).

\section{Buddhism}

In Buddhism it is taught that the strategy of the Eightfold Path to nirvana (the ultimate destiny of existence) and the philosophy behind it is known to invoke the core virtues of humanity, justice, temperance, transcendence and wisdom (Peterson \& Seligman, 2004).

\section{Hinduism}

The emphasis in Hinduism is on personal virtues, such as selfdenial and renunciation; these promote self-improvement in the current life and potential for salvation or the attainment of a higher caste in the next life (Peterson \& Seligman, 2004).

\section{Biological approaches:}

Lennick and Kiel (2005) highlight the Nature versus Nurture debate. They use the analogy that we need moral software, the programming that our moral hardware relies on to make moral choices. Like any other human capacity, morality is a combination of our biology (our nature) and our experiences (nurture). They further hold that we grow morally through the interplay between our biological disposition to be empathetic and through our loving relationship with our parents. This is shown in the behaviour of six or seven year olds who are able to tell right from wrong and experience guilt when participating in activities that are wrong (Lennick \& Kiel, 2005).

Temperament and personality also have a role to play in character development. Investigations of temperament have shown how biologically-based individual differences in sociability, emotionality, and activity level channel subsequent personality development (Park, 2004). Twin studies of both adults and children have found that empathic behaviours and prosocial patterns of behaviours are heritable (Park, 2004).

One final thought to consider regarding the various perspectives discussed, which was put so succinctly by Canella and Monroe (1997, p. 2), is that "theorizing is imperfect." Therefore multiple perspectives are necessary to explain the complexity surrounding character development in people. In summary of the above discussion, what is commonly found running through each approach is the influence that social interaction (with family, role models, friends, educators and political institutions) has on character development. The statement "character is social in its institution" (Hunter, 2000, p. 15) can be reiterated here and is greatly applicable to the workplace which is also regarded as a social institution (Wikipedia Free Encyclopedia, 2006). What follows next is a discussion of the possible ways that character develops in the workplace.

\section{Character development in the workplace}

Most organisations do not have "developing character" in mind when they plan leadership training and development programmes in their organisations. According to Adair (2005), growing leaders transcends organisations, as leaders are developed in families, schools and universities; however, it is the responsibility of organisations to grow leaders. Adair (2005) suggests that organisations should select candidates who have personal qualities of character, such as integrity, reliability and stability, leadership and teamwork abilities, decision-making abilities, communication abilities and self-management abilities. Adair further states that these candidates should be trained and educated to work together in harmony to fulfill the generic role of a leader.

As mentioned earlier, there is a lack of literature on the development of character as a multidimensional construct, however there have been studies done on the development of various elements of character, particularly in the workplace. As in the case of the study of the development of wisdom, Hartman (2000), cited in Peterson and Seligman (2004), found that the accumulation of a wide range of adult experiences precedes the development of wisdom. These could include mentoring in the workplace and successful resolution of crises and hardship. Another example is that of perseverance which develops through social support, receiving positive feedback and reward, and selfcontrol (Peterson \& Seligman, 2004). Individual integrity, for instance, is known to develop through social support provided by multiculturalism and diversity awareness (Peterson \& Seligman, 2004). This is greatly applicable to the South African work context.

There are, however, two leader character development approaches worth mentioning. Klann (2003) proposes the Five E's approach: Example (leaders lead by example), Education (formal and informal training), Environment (organization's culture), Experience (experiential training) and Evaluation (feedback on developmental experience). Khurana and Snook (2004) prescribe another novel intervention to develop character in military cadets: inspire them to react emotionally to situations, getting cadets out of their comfort zones, and a structured reflection and meaning-making process to influence each cadet's identity.

A study conducted on perceived leader integrity and the ethical intentions of subordinates, revealed that subordinates who do not adhere to a belief in universal moral values, intentions to commit unethical acts decreased as the perceived integrity of their leaders increased (Peterson, 2004). This presents a notion that the character of a leader has a direct influence on whether or not subordinates will commit unethical acts, thus indirectly developing character in the workplace. A leader of character can further influence his/her followers by communicating belief in employees, encouraging reciprocal disclosure of beliefs and goals, and contracting for mutual feedback and mutual accountability in their performance development initiatives (Lennick \& Kiel, 2005).

\section{RESEARCH DESIGN}

\section{Research approach}

With a definition of character in mind, having unpacked its constituent elements, and with an understanding of how character is developed, field work was undertaken to understand perceptions of character in the workplace, and how it is developed. To this end, a qualitative research design was selected. The design was primarily non-empirical, but was supported by a limited number of empirical interviews. 
Research Methodology

Participants

Six individuals, each from different work settings, were chosen for the study (refer to Table 3). Each of these individuals were considered by the researchers to be leaders of sound character.

TABLE 3

ParticipanT's Profile

\begin{tabular}{lll}
\hline & Position & Sector/Industry \\
\hline Participant 1 & Chief Executive Officer & Information Technology \\
Participant 2 & Director & Legal \\
Participant 3 & Senior Pastor & Religious Institution \\
Participant 4 & Group Manager & Recruitment Agency \\
Participant 5 & Salesperson & Information Technology \\
Participant 6 & Chief Operating Officer & Recruitment Agency \\
\hline
\end{tabular}

Methods of data gathering

In-depth interviews using semi-structured questions were conducted at each of the participants' workplaces. Purposeful sampling was used as it allows one to "discover, understand, gain insight" through the selection of "a sample from which one can learn the most" (Merriam, 1988, p. 48). Generic considerations such as obtaining informed consent and protecting the participants, anonymity, and situation-specific issues were taken into account during the execution of the research (Schurink, 2005).

The following research questions were asked:

- What are the prime elements/categories of character?

- How does character develop?

- How is your character revealed through your role as a leader?

- Describe the importance of character in leadership?

- How does your organisation develop leaders?

- What is the employers' responsibility in developing character in future leaders?

\section{Procedure}

A digital tape recorder and field notes were used to record the indepth interviews. Thereafter, each tape recording was transcribed, analyzed, stored and safeguarded.

\section{Data analysis}

Themes that emerged were evaluated against the theories of the phenomenon of character development in leaders as reviewed above. The data was evaluated using the criteria postulated by Lincoln and Guba (1985, cited in Roberts \& Llardi, 2003), which is credibility, transferability, dependability and confirmability. The data was analysed manually.

\section{RESULTS}

As with any qualitative study a large amount of rich data was generated. The data presented in Table 4 refers to core character elements that the participants regarded as important for potential leaders and existing leaders to exhibit in their working lives. They are listed from the most frequently mentioned element to the least often mentioned element. All of the participants supported leadership as a character element; $80 \%$ supported integrity; 50\% industriousness, empathy and loyalty; $30 \%$ optimism, fairness and compassion and the remainder of the character elements were $10 \%$ supported.
TABLE 4

KEY CHARACTER ELEMENTS FOR LEADERSHIP

\begin{tabular}{|c|c|}
\hline Character Element & Supporting extract \\
\hline Leadership & $\begin{array}{l}\text { 'I think another characteristic of a leader is enabling } \\
\text { other people to do the job'; 'Lead by example'; 'I find } \\
\text { that if you're a good leader, people will do almost } \\
\text { anything for you and its not, it becomes not about } \\
\text { the money, it becomes about the fulfillment of the } \\
\text { individual, so if you self-satisfy people and give them } \\
\text { fulfillment as a leader and inspire them they will do } \\
\text { anything, I think you develop the work ethic' }\end{array}$ \\
\hline
\end{tabular}

Integrity/Faithfulness 'People who are true to their word and who can be trusted under any conditions'; 'Consistency and passion in executing tasks is not congruent with consistency and passion in words'; 'A lot to do with what they committed to and what they deliver after their commitment' 'Faithful in the little things, such as obeying company rules eg. coming on time to work'

Industriousness 'The ethical side of character and also your ability to work hard and also produce high quality work, those three things go hand in hand'

Empathy/Emotional 'How you get the best out of people and the leader is engagement only as good as his/her people'; 'Empathy I believe underpins all aspects of leadership, you have to fundamentally put yourself in someone else's shoes to understand what their needs are in their positions, in order to really communicate effectively'; 'Understand what people under you are doing in their jobs, for example, wash dishes for a day, this enables getting a balanced perspective and builds respect from your subordinates'

Loyalty/Commitment 'Loyal to yourself, to others and to the company protects the company image'; 'An unselfish commitment to helping other people, fundamental around the concept of love'

Optimism/Positive 'Demonstrated in the passion that people display for attitude the company that they work for'; 'Leaders need to look at whether people will do more than they are asked'; 'If things don't go their way, character says, it doesn't matter if things go your way or not your way, what is important to the company becomes important to you'

Fairness 'Applying rules consistently'; 'Giving people equal opportunity'

Compassion

Love

The humane side that they need to deal with in terms of offering counseling'

'Service in the concept of love, unselfishly caring about, moving from those words service to the term customer service, this is universal and the principles that underpin these extends further into the concept development of people, maximizing people development and bringing the best out in people and watch them grow.

Humour

'There's a lot of people that joke in the business, it is not unhealthy, as long as boundaries are managed and there is professionalism

Self-discipline 'Being accountable for every activity in the organisation, for example salesman that go out cannot always account for their time, requires self discipline'; 'To adhere to the company's policies and procedures'; 'Not doing what you want to do'

Perseverance

'Perseverance is an inbred desire or passion for you to want to achieve something'

Self-confidence 'Any decision that a leader makes you have to make it confidently, whether it is good or bad'

Humility

'Should come out in the way we engage as leaders with people'; 'Never thinking that you are bigger or better than others, attitude of always place to learn

Self-knowledge 'Most people do not know their character strengths and weaknesses'; 'They are dishonest with themselves'

Initiative 'Aspiring to be'; 'They don't necessarily wait for others to develop them'

Conscience

Creativity

'Whether you acting right or wrong'

'Reinventing yourself'; 'People coming up with new and innovative ideas'

Spirituality
'Through pain you learn to discover where you draw strength from , inevitably it goes beyond yourself, your family, to your spiritual dimension' 
The findings indicate that the leaders take their leadership roles seriously, as leadership was considered the most important character element by all the participants. The finding that integrity is the second most important character element asserts the belief that without it in leadership, there is no trust of followers (Manning \& Curtis, 2003).

The data presented in Table 5 represents the participants' understanding of the way character develops in life. Table 5's identified themes and supporting extracts reflects the participants' recognition that environmental factors, such as a person's upbringing and role models, influence character development. These findings support the literature reviewed.

\section{TABLE 5}

\section{THEMES IDENTIFIED FROM PARTICIPANTS' UNDERSTANDING OF THE} WAY CHARACTER DEVELOPS IN LIFE

\begin{tabular}{|c|c|}
\hline Identified theme & Supporting extract \\
\hline Person's upbringing & $\begin{array}{l}\text { 'Bad or good childhood, each experience can be } \\
\text { worthwhile'; 'Parents discipline you' 'Starts with the } \\
\text { role models that you engage with when you are at } \\
\text { your earliest years of consciousness, that is your } \\
\text { immediate family'; 'Your value system teaches you } \\
\text { how to deal with different kinds of people'; 'Helps you } \\
\text { to identify the difference between right and wrong' }\end{array}$ \\
\hline Role models & $\begin{array}{l}\text { 'Unselfishly caring about other people and that you } \\
\text { have to build through experience of observing how } \\
\text { other people, who you look up to' }\end{array}$ \\
\hline Value system & $\begin{array}{l}\text { 'Your value system teaches you how to deal with } \\
\text { different kinds of people'; 'Helps you to identify the } \\
\text { difference between right and wrong'; 'Having positive } \\
\text { role models' 'This provides a foundation of value that } \\
\text { will help you through the challenges of life.' }\end{array}$ \\
\hline Self-discipline & $\begin{array}{l}\text { 'Example: training yourself to play soccer'; 'You don't } \\
\text { realize it when you are young that your character is } \\
\text { being built' }\end{array}$ \\
\hline $\begin{array}{l}\text { Relationship with } \\
\text { spouse }\end{array}$ & $\begin{array}{l}\text { 'Your wife can discipline you'; 'Integrity and fidelity } \\
\text { go hand in hand' }\end{array}$ \\
\hline Church environment & 'You can be disciplined' \\
\hline $\begin{array}{l}\text { Personal crisis and } \\
\text { trauma }\end{array}$ & $\begin{array}{l}\text { 'The pain associated with anxiety causes you to think } \\
\text { long and hard about the issues and to work through } \\
\text { they, inevitably become mature'; 'You discover what } \\
\text { is right from wrong'; 'The crisis has to be } \\
\text { constructively challenged'; 'Your character cannot } \\
\text { develop if you don't go through sometimes very } \\
\text { negative circumstances' }\end{array}$ \\
\hline Religion & $\begin{array}{l}\text { 'If you heed what the Bible is telling you, you will } \\
\text { not come off tracks' }\end{array}$ \\
\hline
\end{tabular}

Table 6's identified themes and supporting extracts reveal that work environmental factors such as difficult clients, good and bad superiors, and the nature of obeying company rules and procedures, each have a role to play in developing character.

\section{TABLE 6}

\section{THEMES IDENTIFIED FROM PARTICIPANTS' UNDERSTANDING OF CHARACTER DEVELOPMENT IN THE WORKPLACE}

\begin{tabular}{ll}
\hline Identified Themes & $\begin{array}{l}\text { Supporting extract } \\
\text { Stress }\end{array}$ \\
& $\begin{array}{l}\text { 'I guess it also builds character is how people deal } \\
\text { with stress and stress related responses because } \\
\text { obviously people deal with stress differently and some } \\
\text { can handle it well and some can't, also how } \\
\text { emotionally engaged we are' }\end{array}$ \\
Nature of clients/ & 'Call Centre clients have many challenges surrounding \\
customers & attrition, productivity, performance results, \\
& environments are very stressful, a blaming culture \\
& exists'; 'Some team members would make an effort to \\
& get to the bottom of get to what is driving the \\
& challenges and take that as a learning and character \\
& building experience'; 'An attorney who does criminal \\
& law, with all respect to them, their minds are warped, \\
because they are dealing with ...criminals, it actually \\
gets difficult for those people to make an informed \\
and correct decision, I've seen this happen, I refuse \\
point blank to do criminal law'
\end{tabular}

Difficulties with 'Difficult challenges, for example flexi staff passing staff members away, deaths; One needs to be quite strong to handle that, the administration obligation and humane obligation(counseling)'; 'The other thing in character development in the workplace, is a the way people rub off good habits and bad habits'; 'You have to develop a hard nose approach to those that have developed bad habits'; 'Dealing with people that steal and come late - handle such situations in an ethical manner (there's no grey area) - HR guiding policy and disciplinary code'.

Good and bad 'Good and bad managers and its built my character as superiors a leader because you know it brings you back to the way you felt when you were treated in a certain way, as long as you never forget it and you apply it to the relevant work situation.'

Company's policies 'The company's policies and processes discipline an and procedures Being disciplined in the workplace Nature of job individual to behave in a certain way'.

'One can either rebel against it or accept it'; 'Accepting discipline in a positive way builds character'

'A company builds your character in the nature of your job; they develop you solely for the purposes of the company; this is not sustainable as they are not working on the real character.'

Work Experience 'I think people who can lead other people have been through areas and experienced, have been there and know what it feels like are therefore able to uplift and inspire people cause they know how it feels'; 'One becomes wise and one gains more skills with experience'

Community invest- 'We have five modules of classroom training around ment programmes the very subjects of leadership, once our team leaders have been to the classroom and learnt the principles of leadership, we then ask that they engage with groups of underprivileged children and that they teach those principles'; 'It builds self confidence, where you really feel good about yourself and make a difference to a young child, and not only that you build a culture of service when you engage with that group of children'; 'So we've discovered that experiential learning and teaching underprivileged children is an incredibly powerful way teaching people empathy

Leadership develop- 'It was a eight module process dealing ment programmes - with leadership, emotional maturity, includes mentoring, project management etc' coaching, technical and soft-skill training.

The participants also gave their viewpoints on the benefits of having a leader of character. In summary, they stated that companies that have leaders that exhibit character are more likely to "attract the right talent, customers and suppliers", which in essence will lead or "translate" into "passion and commitment" from employees, business performance and ultimately the achievement of organisational goals. This in turn, will eventually lead to sustainability and stability through difficult, challenging and fast-moving work environments.

The participants also believed that an organisation should maximize character development within the organisation, but that exclusive responsibility should not be taken for it. One participant held that it made "good commercial sense" and that "in order to deliver excellent customer service, to achieve profitable results for our shareholders we have to grow and develop the staff." The participants held that it is the individual's responsibility to take ownership of his/her character development, and that a company will develop your character only in terms of the nature of your job. One participant held that it is a leader's responsibility to build a follower's character for the purpose of taking a person to a higher level in life. This can be achieved through motivation and support. One participant held that his organisation focuses their development initiatives on the slogan 'training for reigning.'

The participants were posed with the question, what roles do leaders play in developing employees' character? They mentioned the following leadership responsibilities: Employers 
should play a role in terms of guiding employees or adding to that building process of character development. One participant argued that "guiding means to help employees get on the right track, providing thoughts and tools for possibly enhancing character, but employees must ultimately take ownership." They further stated that this can be achieved by creating a work environment that is optimal for character development, being a leader of character, building trust, teaching two-way communication, allowing employees to make mistakes and allowing employees to experiment.

\section{DISCUSSION}

Leadership, integrity, industriousness, empathy, loyalty, optimism, fairness and compassion were regarded as the most important elements of character that are sought after in leaders in the workplace. In essence, Table 4's findings support the idea that to be a great leader means to lead out of character.

Leading out of character is complex as it requires the interrelationship between the various elements of character. If one considers Peterson and Seligman's (2004) categorization of character strengths, and Lickona's (1991) components of good character, the following stands out: character depends on the interplay and harmonious working of the cognitive, emotional, spiritual, social and work dimensions of a person's life. These dimensions, and the perspectives discussed in the literature review, provide a rich understanding of the complexity surrounding character.

The supporting extracts in Table 5 and 6, regarding the way character is believed to develop in life and in the workplace specifically, can possibly be viewed as situational themes (specific habits that lead people to manifest given character strengths in given situations, as postulated by Peterson and Seligman (2004)). This confirms Baumrind's (1998) standpoint that character consists of cultivated habits. It is through the cultivation and display of "good habits" that one can see tangibly what character is. One can begin to understand Manning and Curtis's (2003, p. 94) statement that "character is who you are" and that "you lead by virtue of who you are." The following statement, made by one of the participants, "the way you honour people, the way you build people, all those type of things that you are they must see", strengthens the above assertion. This assertion is further supported by Scarnati (2002), who stated that everything a leader says, does, and every feeling that a leader expresses, is observed by others, and has an effect on the organisation.

Table 5 and 6 also serve to confirm that character development is a continuous life-long process, starting in early childhood and continuing through adulthood. It encompasses the influence of that which is inherent (moral software, temperament, cognitive ability), that which is an environmental influence (childhood, adolescence and adult life experiences), and a person's own efforts, for example through the activation of "self-discipline". What still stands, however, from the findings is that character development in an organisation rests upon the shoulders of the individual leader. Leaders have to lead "by example", inspire and develop employees. This is a crucial responsibility of the leader if one considers Kohlberg's standpoint that the majority of adults never reach stage six in moral development, a stage characterized by respect for universal principles and social conscience (Barger, 2000). This concern is further heightened by a study that revealed that leaders that exhibit high perceived integrity and strong beliefs in universal moral rules are associated with lower intentions of employees to commit unethical acts (Peterson, 2004).

Another point of importance that is reflected in the findings is that character development occurs through the daily work experience of leaders and employees interacting with one another, interacting with clients, performing one's daily work tasks and dealing with complex challenges. However, it does require willingness and the openness on the part of the individual to develop him/herself. It is worth noting that, according to Adair (2003, p. 10), all "leadership qualities can be developed - some more than others - by practice and experience". Jaworski and Senge (1996, p. 7) view leadership development as a participation in an unfolding future that has more to do with our "being - our total orientation of character and consciousness - than with what we do."

The findings also indicate that organisations are willing to assist employees and future leaders in developing their character but they believe that the onus of character development rests with the individual. Leaders and their organisations therefore play a supportive role by creating a work environment that is conducive for character development, as this creates a culture of service, and in the end, sustainability. The findings further highlight that leaders are seeking to develop employees with leadership potential who have the leadership attributes that Adair (2005) mentions: Leadership and teamwork, including qualities of personality and character, such as energy, enthusiasm and initiative; Decision-making; thinking skills in the applied forms of problem-solving, decision-making, and creative and innovative thinking; and Communication skills (speaking, listening, writing, and reading).

\section{Conclusion}

This study explored what organisational leaders consider to be the key character elements of leaders within the workplace and it was found that leadership, integrity, industriousness, empathy, loyalty, optimism, fairness and compassion were regarded as the most important elements of character that are sought after in leaders in the workplace.

The study also found that the influence of environmental work factors (for example clients and good and bad superiors), a person's own efforts, and the daily work experiences of leaders led to the development of their character. Organisations are and can continue the process of character development in their leaders by providing a supportive role through the creation of work environments that are conducive to character development and through various developmental initiatives such as mentoring and soft-skill training. What was also demonstrated in the findings is that organisations are willing to assist in continuing the development of character in their employees, but the onus of character development lies with the individual employee.

The essence of a great leader lies in the development of character elements through habitual action. Different elements of character and the degree to which they are reflected varies in different leadership work contexts, for example a higher level of conceptual skills is needed for vice presidents than department heads (Newstrom \& Davis, 2002, p. 166). Character provides the platform upon which leaders can be authentic and serve their followers. However, there is still much ignorance regarding what character is and its overall benefits for an organisation. Sometimes character is confused with personality.

A leader is considered, only as good as his/her followers are. This statement is supported by Adair $(2003$, p. 84 ) who believes that "any good leader has a product - a high-performance team." This can be measured by the level of trust and commitment that one's followers have towards one. In the final conclusion, Maxwell (1998) maintains that to build trust a leader must demonstrate competence, connection and character, and the greatest of these is character. Trust, according to Rossouw and van Vuuren (2004), facilitates co-operation, unlocks knowledge and promotes loyalty. These functions of trust provide the bedrock upon which an organisation will achieve success. In the end it is all about relationship which hangs on the demonstration of two great moral values: "respect" and "responsibility" towards oneself, others and the environment (Lickona, 1992, p. 43-44). 


\section{RECOMMENDATIONS}

Based on the literature and the findings, it is suggested by the researcher that organisations use Klann's Five E's approach (2003) to continue the development of character in their employees and future leaders. This approach, mentioned briefly before, is expanded upon in Table 7.

TABLE 7

KLANN'S FIVE ES APPROACH TO CHARACTER DEVELOPMENT

\begin{tabular}{|c|c|}
\hline FIVE Es & Approach \\
\hline Example & $\begin{array}{l}\text { - Leaders should lead by example, by displaying the } \\
\text { character ethic in their organisations. } \\
\text { - Create an environment of trust with their followers. } \\
\text { - Provide guidelines and be the first to follow them. }\end{array}$ \\
\hline Education & $\begin{array}{l}\text { - Formal and informal training, through the use of } \\
\text { leadership development programmes. } \\
\text { - Personal leadership development programmes, that } \\
\text { develop character-based, principle-centered, inside- } \\
\text { out leaders. } \\
\text { - Emotional intelligence facilitation (Amos, Ristow and } \\
\text { Ristow, 2004, pp. 227-229) }\end{array}$ \\
\hline Environment & $\begin{array}{l}\text { - Build an ethical culture. } \\
\text { - Develop an ethical code of conduct. } \\
\text { - Disciplinary codes and the enforcement thereof. } \\
\text { - Build a learning culture through the use of teams. } \\
\text { - Promote spirituality in the workplace (Nel, Gerber, van } \\
\text { Dyk, Haasbroek, Schultz, Sono \& Werner, 2001, p. 307) }\end{array}$ \\
\hline Experience & $\begin{array}{l}\text { Experiential training, through job-related experiences } \\
\text { with managers, colleagues, community investment } \\
\text { projects and customers } \\
\text { - Coaching and mentoring processes that provide career } \\
\text { and psychosocial support (Noe, 2005, pp. } 289 \text {-291) }\end{array}$ \\
\hline Evaluation & $\begin{array}{l}\text { - Personality assessment (Bergh and Theron, } 2005 \text {, } \\
\text { pp. 446-447) } \\
\text { - Feedback on developmental experiences that focuses on } \\
\text { most important character elements for one's leadership } \\
\text { role. } \\
\text { - Reinforcement through the use of positive and negative } \\
\text { rewards. }\end{array}$ \\
\hline
\end{tabular}

Source: Klann (2003, pp. 5-6)

It is further suggested that leaders assess their own character, using the three criteria mentioned by Manning and Curtis (2003). These three criteria are based on the way employees assess character, which are: (a) what leaders say is important; (b) what leaders do is more important (is there congruency between a leader's words and actions?); and (c) what leaders sacrifice is most important (caring to the point of personal sacrifice is regarded as the highest form of living by one's values).

\section{Suggestions for further research}

It is recommended that investigations into the development of character as a family of positive traits - a multidimensional construct - should be done in the workplace. The researcher further suggest that the development of character in reference to the social, spiritual, cognitive, and emotional dimensions of a person's life and the interdependency that exists among them as dimensions should be further investigated to understand the complexity of character as a multidimensional construct.

"The only thing that walks back from the tomb with the mourners and refuses to be buried is the character of a man. This is true. What a man is, survives him. It can never be buried." J. R. Miller

\section{REFERENCES}

Adair, J. (2005). How to grow leaders. The seven key principles of effective leadership development. Great Britain: Kogan Page Limited.

Adair, J. (2003). Not bosses but leaders. The way to success. Great Britain: Kogan Page Limited.

Amos, T, Ristow, A. \& Ristow, L. (2004). Human Resource Management. (2nd ed.). Lansdowne: Juta \& Co. Ltd.

Anderson, G.L. (1997). Identity and character development: Individual in community. International Journal of World Peace, 14 (4), 41.

Badarocco, J.L. (1997). Defining moments. Boston, Massachusetts: Harvard Business School Press.

Barger, R.N. (2000). A summary of Lawrence Kohlberg's stages of moral development. University of Notre Dame. Retrieved on August, 12, 2006 from http://www.nd.edu/ rbarger/kohlberg.html.

Barnard, H. (2003). The anthropological presuppositions of Personal and Professional Leadership. Unpublished masters essay. Johannesburg: Rand Afrikaans University.

Beatty, R., Ewing, J.R \& Tharp, C. (2003). HR's role in corporate governance: present and prospective. Human Resource Management, 42 (3), 3.

Bellingham, R. (2003). Ethical leadership: rebuilding trust in corporations. Amherst, Mass: HRD Press.

Bergh, Z.C. \& Theron, A.L. (2005). Psychology in the work context. ( $2^{\text {nd }}$ ed.). Cape Town: Oxford University Press Southern Africa.

Canella, A.A. \& Monroe, M.J. (1997). Contrasting perspectives on strategic leaders: Toward a more realistic view of top managers. Journal of Management, 23 (3). (Business Source Premier Database, Ref. No. 9708224783).

Cashman, K. (1998). Leadership from the inside-out. Provo: Executive Excellence Publishing.

Coetzee, M. (2006). Career planning in the 21st century. Cape Town: Juta \& Co.

Corsini, R.J. (1999). The Dictionary of Psychology. USA: Taylor \& Francis Group.

Covey, S.R. (1994). The Seven Habits of Highly Effective People. New York: Simon \& Schuster.

Covey, S.R. (1997). Seven habits of global executives. Executive Excellence, 14 (12), 3-4.

Covey, S.R. (2004). The $8^{\text {th }}$ Habit. From effectiveness to greatness. Great Britain: Simon \& Schuster.

Cresswell, J.W. (1998). Qualitative Inquiry and Research Design: Choosing among five traditions. California: Sage Publications.

Farmer, R.T. (2005). Corporate culture defines a company and future. Mid-American Journal of Business, 20 (2), 7-9.

Huitt, W. (2004). Moral character development. Educational Psychology Interactive. Retrieved on August, 16, 2006 from http://teach.valdosta.edu/whuitt/col.

Hunter, J.D. (2000). The death of character. New York: Basic Books.

Gray, K.R. \& Clark, G.W. (2002). Addressing corporate scandals through business education. International Journal of World Peace, 19 (4), 43-62.

Halsey, W.D. \& Friedman, E. (1981). Collier's Encyclopaedia 5. New York: Macmillan Education.

Haste, H. , Markoulis, D. \& Helkama, K. (1999). Morality, wisdom and life-span. Chapter 7. In Demetriou, A., Doise, W. \& van Lieshout, C. (Eds.). Life Span Developmental Psychology. England: John Wiley \& Sons Ltd.

Ilies, R., Morgeson, F.P., \& Nahrgang, J.D. (2005). Authentic leadership and eudaemonic well-being: Understanding leaderfollower outcomes. The Leadership Quartely, 16 (3), 373-394.

Jaworski, J. \& Senge, P. (1996). Synchronicity: The Inner Path of Leadership. USA: Berrett-Koehler Publishers Inc.

Jordaan, W. \& Jordaan, J. (1998). People in Context. (3rd ed.). Heinemann Johannesburg.

Khurana, R. \& Snook, S. (2004). Developing leaders of character. In Gandossy, R. \& Sonnenfeld, J. (Eds.). Leadership and governance from the inside out. New Jersey: John Wiley \& Sons Inc. 
Klann, G. (2003). Character Study: Strengthening the heart of good leadership. Leadership in action. 23 (3), 3-7.

Lennick, D. \& Kiel, F. (2005). Moral Intelligence: Enhancing business performance and leadership success. Upper Saddle River: Wharton School Publishers.

Lickona, T. (1991). Educating for character: How our schools can teach respect and responsibility. New York: Bantam.

Manning, G. \& Curtis. K. (1998). The Art of Leadership. New York: Mc Graw Hill.

Maxwell, J.C. (1998). The 21 Irrefutable Laws of Leadership. Nashville: Thomas Nelson Publishers.

Maxwell, J.C. (2002). The most important ingredient of leadership: Integrity. In Graves, S.R. \& Addington, T.G. Life @ Work on Leadership. San Francisco: Jossey-Bass.

McDaniel, A.K. (1998). Character Education: developing effective programs. Journal of Extension. 36 (2). Retrieved on June, 13, 2006 from http://www.joe.org/joe/1998april/ a3.html.

McElmeel, S.L. (2002). Character Education. A guide book for teachers, librarians and parents. USA: Libraries Limited.

Merriam, S.B. (1988). Case study research in education: A qualitative approach. San Francisco: Jossey-Bass Publishers.

Miller, G. (2004). Leadership and integrity: How to ensure it exists in your organization. The Canadian Manager, 29 (4), 15-17.

Miller, J (2003) Organizational future solutions: Integrity. Futurics, 27 (3/4), 105-106.

Nel, P.S., Gerber, P.D., van Dyk, P.S., Haasbroek, G.D., Schultz, H.B.,Sono, T. \& Werner, A. (2001). Human Resource Management. (5th ed.). Cape Town: Oxford University Press Southern Africa.

Newstrom, J.W. \& Davis, K. (2002). Organisational Behaviour. Human behaviour at work. (11 ed.). United States: McGrawHill Companies, Inc.

Noe, R. (2005). Employee Training and Development. (3rd ed.). Boston: McGraw - Hill International.

Nucci, L. (1997). Moral development and character formation. In Walberg, H.J. \& Haertel, G.D. Psychology \& Educational Practice. Berkeley: MacCarchan.

Park, N. (2004). Character strengths and positive youth development. In Peterson, C. Positive Development: Realizing the potential of youth. The Annals of the American Academy of Political and Social Science (Eds.). CA: Sage Publications.

Peterson, C. \& Seligman, M.E.P. (2004). Character strengths and virtues. A handbook of classification. American Psychological Association. Oxford University Press.
Peterson, D. (2004). Perceived leader integrity and ethical intentions of subordinates. Leadership \& Organization Development Journal, 25 (1/2), 7-23.

Roberts, M.C. \& Llardi, S.S. (2003). Handbook of research methods in Clinical Psychology. United Kingdom: Blackwell Publishing Ltd.

Rossouw, D. \& van Vuuren, L. (2004). Business Ethics. (3rd ed.). Cape Town: Oxford University Press.

Rossouw, G.J. \& van Vuuren, L.J. (2003). Modes of Managing Morality: A Descriptive Model of Strategies for Managing Ethics. Journal of Business Ethics, 46 (4), 389-402.

Scarnati, J.T. (2002). Leaders as role models: 12 Rules. Career Development International. Bradford, 7 (3),181-189.

Schurink, W. (2005). Qualitative Research: Introducing key features of an Interpretative approach to Social Science Research. Lecture 14: Qualitative Research Proposal Writing. Department of Human Resource Management. University of Johannesburg.

Sankar, Y. (2003). Character not charisma is the critical measures of leadership excellence. Journal of Leadership \& Organizational Studies, 9 (4), 45-55.

Smith, D.P.J. (2004). Leadership Development Portfolio for M.PhilHRM (PiPL) Programme. Department of Human Resource Management. Auckland Park: Rand Afrikaans University.

Smith, D.P.J. (2005). The PPL - Temperament Typology Facilitator Workbook. Auckland Park: University of Johannesburg.

Social Organisation from Wikipedia Free Encyclopedia. Retrieved on November 12, 2006 from http://en.wikipedia.org.

Spears, L.C. (2006). On character and servant leadership: Ten characteristics of effective, caring leaders. The Greenleaf Centre for Servant Leadership. Retrieved on October, 23, 2006 from http://www.greenleaf.org.

Stanford Encyclopedia of Philosophy. Retrieved on August, 10 2006 from http://plato.stanford.edu.

Storey, M.A. (2003). Bringing head and heart to coaching. Organization Development Journal, 21 (2), 77-78.

Storr, L. (2004). Leading with integrity: A qualitative research study. Journal of Health Organization and Management, (18) 6, 415-434.

The Josephson Institute. Character Counts. Retrieved on October, 18, 2006 from www.charactercounts.org.

The New International Version Rainbow Study Bible. (1996) USA International Bible Society.

Turknett, R. , Turknett, L. \& McCusker, C. (2006). Going First and Being Followed: Leading with Knowledge and Integrity. Retrieved on January, 16, 2006 from http://www.southerninstitute.org.

Verrier, D. (2004). Executive coaching: A personal and professional leadership (PPL) perspective. D.Phil Thesis. Auckland Park: Rand Afrikaans University. 